\title{
Adult human retinal pigment epithelial cells capable of differentiating into neurons( Abstract_要旨)
}

$\operatorname{AUTHOR}(S)$ :

Amemiya, Kaori

\section{CITATION:}

Amemiya, Kaori. Adult human retinal pigment epithelial cells capable of differentiating into neurons. 京都大学, 2007, 博士(医学)

ISSUE DATE:

2007-05-23

URL:

http://hdl.handle.net/2433/135754

RIGHT: 
氏 名雪窝かおり

学位 (専攻分野) 博士(医学)

学位記番号医 博 第 3134 号

学位授与の日付平成 19 年 5 月 23 日

学位授与の要件 学 位 規 則 第 4 条第 1 項 該 当

研究科. 専攻医学研究科外科系専攻

学位論文題目 Adult human retinal pigment epithelial cells capable of differentiating into neurons.

(成人ヒト網膜色素上皮細胞の神経への分化能)

論文調查委員教主授影山龍一郎教授野田亮教授山中伸弥

\section{論文内容 の 要旨}

哺乳類において、成体の中枢神経系では神経の再生は起こらないと考えられてきた。しかし胎生期にみられたような神経 幹細胞が成体になっても存在し、神経新生が起こっていることが、様々な実験で明らかにされている。

眼組織では、網膜前駆細胞が胎生期網膜に存在しており種々の網膜細胞へと分化するが、成体でも毛様体上皮細胞に存在 する網膜前駆細胞から、あるいは虹彩上皮細胞、網膜色素上皮細胞を用いて神経細胞への分化誘導を試みる実験がされてい る。

ニワトリやラット網膜色素上皮細胞に関してはでレンズ上皮に分化転換することが古くから知られており、またニワトリ の網膜色素上皮細胞は神経網膜に分化することも報告されている。哺乳類では、胎生ラットの網膜色素上皮細胞が神経細胞 に分化転換するが、この能力は胎生 14 週までは認めるあのの、胎生 15 週以降ではこの分化転換能は消失すると報告され ている。

成体ほ乳類網膜色素上皮細胞で本当に分化転換能が失われているかを成人ヒト網膜色素上皮細胞を用いて検討した。

ARPE19 および 80 才のヒトから分離された H80HrPE（80-year-old human differentiated pigmented epithelial cells）-6 のふたつの細胞株を用いて評価を行った。まずこれらの細胞を $8 \%$ ウシ胎仔血清添加のもと培養し、その後神経幹細胞の培 養条件すなわち $20 \mathrm{ng} / \mathrm{ml}$ bFGF を添加した無血清培地で培養した。神経への分化誘導は bFGF を除去し 13cis レチノイン酸 を含んだ無血清培地で行い、細胞はそれぞれの段階で免疫細胞化学的に評価した。

8\%ウシ胎仔血清下で 2 種の網膜色素上皮細胞株細胞はともに扁平な上皮様の形態を呈し、全ての細胞で $\beta$ III チュブリン を発現した。bFGF を加えた無血清培地での神経幹細胞の培養条件下では、徐々に細胞体が丸みを帯び形態が变化した。さ らにレチノイン酸を加えた無血清培地で神経分化を誘導したところ、神経突起様に突起を伸ばし、 $\beta$ III チュブリンを呈する あのだけでなく、さらに成熟した神経細胞で発現する MAP5、およびニューロフィラメント 200 陽性細胞を認めた。これら の結果はいずれの細胞株でも認めたが、若年のヒトから分離された ARPE19 細胞においてょり高い割合で陽性細胞を認め た。一方、神経分化誘導条件下で培養しても、視細胞のマーカーであるオプシン陽性細胞は認めず、また神経幹細胞では大 半がグリア細胞に分化する条件である $10 \%$ 血清添加培地での培養であグリア細胞のマーカーである GEAP を発現した細胞 認められなかった。

これより、神経網膜と発生起源をおなじくする網膜色素上皮細胞は神経細胞に分化する能力を有すると考えられた。但し より一層網膜に特異的な神経細胞への分化を促すためには、この培養条件では不十分であった。又、神経細胞への分化は認 めたもののグリア細胞への分化はないこと、あとあと幼弱な神経細泡のマーカーとされる $\beta$ III チュブリン陽性細胞であるこ とから、網膜色素上皮細胞の細胞株は神経前駆細胞様の性質を持っている可能性があると思われた。 


\section{論 文 審 査 の 結 果 の 要 旨}

哺乳類において胎生期にみられたような神経幹細胞が成体になっても存在し、神経新生が起こっていることが、近年様々 な実験で明らかにされている。

本論文では、眼組織における神経幹細胞、前駆細胞について、成人ヒト網膜色素上皮細胞を用いて検討された。ARPE19 および H80HrPE-6 の細胞系が用いられた。ウシ胎仔血清添加培地にて培養、そののち神経幹細胞維持条件で培養した。神 経分化を誘導するためにレチノイン酸を含んだ無血清培地で培養した。細胞はそれぞれの段階で免疫組織化学的に評価した。 ウシ胎仔血清添加培地下で細胞は上皮様の形態を呈し、全ての細胞で $\beta$ III チューブリンを発現した。神経幹細胞の培養条件 下では、徐々に形態が変化した。さらにレチノイン酸を加えた無血清培地で神経分化を誘導したところ、徐々に神経突起椂 に突起を伸ばし、 $\beta$ チューブリンを呈するむのだけでなく、さらに成熟した神経細胞で発現する MAP5 陽性細胞、招よびニ ューロフィラメント 200 陽性細胞を認めた。

これらの結果はいずれの細胞系でも認めたが、より若年のヒトから分離された細胞で高い割合で陽性細胞を認めた。しか し、神経分化誘導条件下で培養してあ、視細胞のマーカーであるオプシン、グリア細胞のマーカーである GFAPを発現した 細胞は認められなかった。

以上の結果より、成体のヒト網膜色素上皮細胞には神経前駆細胞としての性質を有する可能性があると考えられた。

以上の研究は、成体哺乳類の組織における神経幹細胞、神経前駆細胞の解明に貢献し、今後の再生誘導の研究の進展に寄 与するところが多い。

従って、本論文は博士 (医学) の学位論文として価值のあるあのと認める。

なお、本学位授与申請者は、平成 19 年 4 月 9 日実施の論文内容とそれに関連した試問を受け、合格と認められたもので ある。 